\title{
A Validated Method for the Detection and Quantitation of Synthetic Cannabinoids in Whole Blood and Urine, and its Application to Postmortem Cases in Johannesburg, South Africa
}

\author{
Dale Pon* iD and Ildiko J. Fenyvesi (iD \\ Department of Forensic Medicine and Pathology, School of Clinical Medicine, Faculty of Health Sciences, \\ University of the Witwatersrand, Johannesburg, WITS, 2050, South Africa. \\ Received 14 March 2017, revised 10 September 2017, accepted 29 January 2018.
}

\begin{abstract}
A LC-HRMS (liquid chromatography coupled with high resolution mass spectrometry) method for the detection and quantitation of several synthetic cannabinoids (JWH-018, JWH-019, JWH-073, JWH-081, JWH-122 JWH-200, JWH-250, AM-2201, (土)-CP 47,497, (C8)-CP 47,497, HU-211) and selected metabolites (JWH-018 N-(4-hydroxypentyl) and JWH-073 $\mathrm{N}$-(3-hydroxybutyl)) in whole blood and urine was developed and validated. These methods were applied to postmortem cases from the Johannesburg Forensic Pathology Services Medicolegal Laboratory (FPS-MLL) to assess the prevalence of these synthetic cannabinoids amongst the local postmortem population. Urine samples were extracted utilizing a solid phase extraction (SPE) method, while blood samples were extracted utilizing liquid-liquid extraction (LLE) method. The accuracy of the analytes ranged from 88-107\% in whole blood (relative standard deviation (RSD) $=7.5-15.0 \%$ ), and from 95-109 \% in urine (RSD = 4.9-11.9\%). The limits of detection (LOD) and the limits of quantitation (LOQ) for the analytes ranged between $0.675 \mathrm{ng} \mathrm{mL}^{-1}$ and $3.375 \mathrm{ng} \mathrm{mL}^{-1}$ in whole blood, and between $0.225 \mathrm{ng} \mathrm{mL}^{-1}$ to $3.375 \mathrm{ng} \mathrm{mL}^{-1}$ in urine. None of the postmortem cases tested positive for any of the targeted analytes. The sample population could be extended to living subjects such as those in drug rehabilitation centres or in hospitals to obtain a more accurate representation of the overall usage in South Africa.
\end{abstract}

KEYWORDS

Toxicology, LC-HRMS, synthetic cannabinoids, whole blood, urine.

\section{Introduction}

Huffman in 1994 designed new compounds with effects comparable to natural cannabinoids like tetrahydrocannabinol (THC). This resulted in the synthesis of JWH-018, which, along with C8 analogues of the cannabinoid CP 47,497 which are the most common synthetic additives in a variety of herbal blends known as 'Spice'. ${ }^{1,2}$ 'Spice' (and associated names such as K2) has been sold in numerous countries since 2004 and is marketed as incense, although it is smoked by users. ${ }^{1}$ Its popularity can be attributed to the fact that commonly used drug tests at the time were unable to detect these drugs in urine and blood as well as its ease of availability, from head shops (shops selling predominantly cannabis-smoking accessories) and the internet. Furthermore, 'Spice' is sold without age restriction by vendors. These products are sold for prices between 5 USD and 15 USD per gram. ${ }^{3,4}$

There have been numerous case reports which have documented the psychopathological and neuropsychiatric effects of certain synthetic cannabinoids.The effects included: blurred vision, tremors, agitation, anxiety, hallucinations, nausea, vomiting, psychosis, paranoia, tachycardia, hypokalemia, and hypertension..$^{5-8}$

In recent years the use of these substances has been found in several countries such as America, ${ }^{9,10}$ the U.K.. ${ }^{10}$ Australia, ${ }^{11,12}$ and Germany, ${ }^{13,14}$ but a comprehensive PubMed search revealed no published research in South Africa.

* To whom correspondence should be addressed. E-mail: dalepon@gmail.com
Methods previously reported included LC-MS/MS, ${ }^{13-16}$ as well as matrix-assisted laser desorption ionisation - time of flight mass spectrometry (MALDI-TOF-MS).$^{17}$ Newer methods include UPLC-TOF ${ }^{18}$ and UPLC-MS/MS. ${ }^{19}$

A validated method for the analysis of these compounds could be instrumental in law enforcement's fight against illegal drugs in South Africa.

\section{Experimental}

\subsection{Reagents, Standards and Samples}

Spice Cannabinoid Mix 1 consisting of JWH-200, JWH-250, ( \pm )-CP 47,497, (C8)-CP 47,497, and HU-211; Spice Cannabinoid Mix 2 consisting of JWH-019, JWH-081, JWH-122, and AM-2201; THC, 11-OH-THC (11-Hydroxy- $\Delta^{9}$-tetrahydrocannabinol), JWH-073, JWH-018 N-(4-hydroxypentyl) metabolite, and JWH$073 \mathrm{~N}$-(3-hydroxybutyl) metabolite solutions were purchased from Cerilliant, Sigma-Aldrich (Round Rock, United States of America). JWH-018 and JWH-200 solutions were purchased from Cayman Chemical (Ann Arbor, United States of America). 1-Naphthalenyl (1-pentyl-1H-indol-3-yl)-methanone- $\mathrm{D}_{11}$ (JWH-018-- $\mathrm{D}_{11}$ ) and (1-Butyl-1H-indol-3-yl)-1-naphthalenylmethanone- $\mathrm{D}_{9}\left(\mathrm{JWH}-073-\mathrm{D}_{9}\right)$ solutions were purchased from Chiron AS (Trondheim, Norway). Analytical grade chemicals were purchased from a variety of suppliers: Beta glucuronidase/ arylsulphatase ((Roche; Basel, Switzerland)); di-potassium hydrogen orthophosphate, sodium carbonate, sodium dihydrogen 
orthophosphate, and sodium hydroxide (Associated Chemical Enterprises, ACE; Johannesburg, South Africa); HPLC-grade acetonitrile, methanol (Honeywell Burdick and Jackson; Muskegon, U.S.A.); HPLC-grade 1-chlorobutane (Minema; Johannesburg, South Africa); ethanol (Radchem; Johannesburg, South Africa); dichloromethane, (RCI Labscan; Bangkok, Thailand); and 1-chlorobutane, formic acid, and sodium acetate (Sigma-Aldrich; Round Rock, U.S.A.). Double deionized water from a Siemens LaboStar evoqua water purifier was used for this research.

A combined synthetic cannabinoids spiking solution was prepared in methanol containing $1 \mu \mathrm{g} \mathrm{mL}^{-1}$ of each of the standards and was stored at $-20^{\circ} \mathrm{C}$. Calibration and Quality Control standards (QCs) were prepared by spiking blank urine and whole blood from known drug-free volunteers at the following concentrations; urine calibration standards: $0.0225 \mathrm{ng} \mathrm{mL}^{-1}$ $0.225 \mathrm{ng} \mathrm{mL} L^{-1}, 1.125 \mathrm{ng} \mathrm{mL}^{-1}, 2.25 \mathrm{ng} \mathrm{mL}^{-1}, 3.375 \mathrm{ng} \mathrm{mL}^{-1}$, $4.5 \mathrm{ng} \mathrm{mL}^{-1}$, and $6.75 \mathrm{ng} \mathrm{mL}^{-1}$; urine QCs: High $\left(4.5 \mathrm{ng} \mathrm{mL}^{-1}\right)$, Medium (1.125 $\left.\mathrm{ng} \mathrm{mL}^{-1}\right)$, and Low $\left(0.1125 \mathrm{ng} \mathrm{mL}^{-1}\right)$; blood calibration standards: $0.0675 \mathrm{ng} \mathrm{mL}^{-1}, 0.675 \mathrm{ng} \mathrm{mL}^{-1}, 3.375 \mathrm{ng} \mathrm{mL}^{-1}$, $6.75 \mathrm{ng} \mathrm{mL}^{-1}, 10.125 \mathrm{ng} \mathrm{mL}^{-1}, 13.5 \mathrm{ng} \mathrm{mL}^{-1}$, and $20.25 \mathrm{ng} \mathrm{mL}^{-1}$; blood QCs: High (13.5 $\left.\mathrm{ng} \mathrm{mL}^{-1}\right)$, Medium (3.375 $\left.\mathrm{ng} \mathrm{mL}^{-1}\right)$, and Low $\left(0.3375 \mathrm{ng} \mathrm{mL}^{-1}\right)$.

A combined internal standard solution was prepared in methanol containing 1-naphthalenyl (1-pentyl-1H-indol-3-yl)methanone- $\mathrm{D}_{11}$ (JWH-018-- $\mathrm{D}_{11}$ ) and (1-butyl-1H-indol-3-yl)-1naphthalenyl-methanone- $\mathrm{D}_{9}\left(\mathrm{JWH}-073-\mathrm{D}_{9}\right)$ at $30 \mathrm{ng} \mathrm{mL}^{-1}$.

Samples were collected at the FPS-MLL (Johannesburg, South Africa) between July 2014 and December 2014. Samples were obtained during routine medico-legal autopsies, where dissection and assessment of the body would be conducted for the purposes of establishing with greater certainty the cause and circumstance of death as per the South African Inquests Act 58 of 1959, Section $2 .^{20}$

The population comprised all cases of unnatural deaths fulfilling the study's acceptance criteria received at the FPS-MLL Johannesburg, which services the Johannesburg metropolitan area, over the 5-month period.

Urine (approximately $5-10 \mathrm{~mL})(\mathrm{n}=85)$ was obtained, where available by puncturing the bladder using a syringe and needle. Blood (approximately $5 \mathrm{~mL})(\mathrm{n}=126)$ was obtained using a syringe and needle from an incision made at the inner femoral region, and if this was unsuccessful, it was obtained from the upper subclavian region.

\subsection{Sample Preparation}

Samples were analysed at the Laboratory of the National Horseracing Authority of Southern Africa situated at the Turffontein Racecourse.

The extraction procedure (adapted from that used routinely at the Laboratory of the National Horseracing Authority of Southern Africa) required $3 \mathrm{~mL}$ of urine sample, calibration standard (urine calibration standards: $0.0225 \mathrm{ng} \mathrm{mL}^{-1}, 0.225 \mathrm{ng} \mathrm{mL}^{-1}$, $1.125 \mathrm{ng} / \mathrm{mL}, 2.25 \mathrm{ng} \mathrm{mL}{ }^{-1}, 3.375 \mathrm{ng} \mathrm{mL}^{-1}, 4.5 \mathrm{ng} \mathrm{mL}^{-1}$, and $6.75 \mathrm{ng} \mathrm{mL}^{-1}$; blood calibration standards: $0.0675 \mathrm{ng} \mathrm{mL}^{-1}$, $0.675 \mathrm{ng} \mathrm{mL} L^{-1}, 3.375 \mathrm{ng} \mathrm{mL}^{-1}, 6.75 \mathrm{ng} \mathrm{mL}^{-1}, 10.125 \mathrm{ng} \mathrm{mL}^{-1}$, $13.5 \mathrm{ng} \mathrm{mL}^{-1}$, and $20.25 \mathrm{ng} \mathrm{mL}^{-1}$ ) and QC (urine QCs: High $\left(4.5 \mathrm{ng} \mathrm{mL}^{-1}\right)$, Medium $\left(1.125 \mathrm{ng} \mathrm{mL}^{-1}\right)$, and Low $\left(0.1125 \mathrm{ng} \mathrm{mL}^{-1}\right)$; blood QCs: High (13.5 ng mL $\left.\mathrm{mL}^{-1}\right)$, Medium (3.375 $\left.\mathrm{ng} \mathrm{mL}^{-1}\right)$, and Low $\left.\left(0.3375 \mathrm{ng} \mathrm{mL}^{-1}\right)\right)$ to be transferred into separate $50 \mathrm{~mL}$ glass tubes. Sodium acetate buffer $(3 \mathrm{~mL}$ of $2 \mathrm{M}$ solution at $\mathrm{pH}$ 5.5) and $20 \mu \mathrm{L}$ of beta glucuronidase/arylsulphatase solution was added to each sample and left to hydrolyse overnight in a water bath at $37^{\circ} \mathrm{C}$. This was followed by the addition of $160 \mu \mathrm{L}$ of $5 \mathrm{M}$ aqueous sodium hydroxide and $3 \mathrm{~mL}$ of $0.25 \mathrm{M}$ phosphate buffer ( $\mathrm{pH} 8$ ). Samples were vortexed and left to stand for $30 \mathrm{~min}$ to reach room temperature, after which $100 \mu \mathrm{L}$ of the combined internal standard solution was added and the samples were centrifuged for $20 \mathrm{~min}$ at approximately $3000 \mathrm{~g}$. Samples were applied to $\mathrm{C}_{18} \mathrm{SPE}$ cartridges conditioned with $2 \mathrm{~mL} \mathrm{MeOH}$ followed by $2 \mathrm{~mL}$ double deionized water. The columns were eluted with $8 \mathrm{~mL}$ dichloromethane:ethanol (96:4), and the eluant subsequently dried under nitrogen gas at $40{ }^{\circ} \mathrm{C}(5-10 \mathrm{psi})$, followed by reconstitution in $100 \mu \mathrm{L}$ methanol.

The method for the analysis of whole blood was based on a previously developed LLE method. ${ }^{21}$ Extraction was conducted by adding $1 \mathrm{~mL}$ of sample, $2 \mathrm{~mL}$ of sodium carbonate buffer ( $\mathrm{pH} 9.0), 50 \mu \mathrm{L}$ internal standard solution $\left(30 \mathrm{ng} \mathrm{mL}^{-1}\right)$, and $10 \mathrm{~mL}$ of 1-chlorobutane: isopropanol (90:10) to a tube. The contents of the tube was mixed, and centrifuged for $15 \mathrm{~min}$ at $3000 \mathrm{~g}$. The tube was frozen in a dry ice bath and the organic layer transferred to a new glass tube. The organic layer was evaporated to dryness under nitrogen gas and reconstituted in $100 \mu \mathrm{L}$ methanol.

\subsection{Instrumentation and Method}

Compounds were separated using an Agilent 1260 Infinity HPLC system with a Waters XSelect CSH C $18,150 \times 2 \mathrm{~mm}(5 \mu \mathrm{m})$ column (purchased from Waters; Milford, U.S.A.). Mobile phase consisted of a gradient of water to acetonitrile, both containing 5 $\mathrm{mM}$ ammonium acetate buffer and $0.1 \%$ formic acid. The linear gradient at $0.3 \mathrm{~mL} \mathrm{~min}{ }^{-1}$ started at 2 min from $2 \%$ to $98 \%$ acetonitrile at $20 \mathrm{~min}$, held at $98 \%$ until $26 \mathrm{~min}$, followed by a return to the initial conditions at $28 \mathrm{~min}$. The detector was a Thermo Fisher Q Exactive Orbitrap High Resolution Mass Spectrometer controlled by XCalibur software set at a scan range of $110-700 \mathrm{~m} / \mathrm{z}$, resolution of 70000 , AGC target balanced, and a maximum injection time of $500 \mathrm{~ms}$. A heated electrospray (HESI-II) ion source was employed using scan to scan positive to negative ion switching.

\subsection{Validation}

This method was evaluated in urine and whole blood for the drugs and metabolites listed in Table 1. Deuterated internal standards were used to compensate for the loss of analyte during sample preparation. The validation was performed in accordance with the guidelines prescribed by SANAS TG 41-01.22 Analytical parameters investigated included selectivity, linearity, limit of detection (LOD), limit of quantitation (LOQ), accuracy, precision, recovery, matrix effects, and stability. Seven calibration standards (two replicates per batch) (urine range: 0.0225-6.75 ng mL ${ }^{-1}$; blood range: $0.0675-20.25 \mathrm{ng} \mathrm{mL}^{-1}$ ) were prepared (in pooled negative urine and whole blood from volunteers) and analysed on four different days for urine and three different days for whole blood. Three QCs (three replicates) were included in each batch.

To assess the selectivity of the method the following criteria were used to process the data: retention time variance $\leq 0.3 \mathrm{~min}$ and accurate mass deviation $\leq 5 \mathrm{ppm}$ was used to check for co-eluting or closely eluting compounds within the same accurate mass range.

Blank samples from five individual non-drug users were analysed with the first batch to check for co-eluting matrix peaks that could give rise to false positive results.

Linearity was assessed using calibration standards over the range: $0.0225 \mathrm{ng} \mathrm{mL} \mathrm{L}^{-1}$ to $6.75 \mathrm{ng} \mathrm{mL}^{-1}$ for urine, and $0.0675 \mathrm{ng} \mathrm{mL}^{-1}$ to $20.25 \mathrm{ng} \mathrm{mL}^{-1}$ for whole blood.

The criteria (based on those used by the Laboratory of the 
Table 1 Validation results.

\begin{tabular}{|c|c|c|c|c|c|c|c|c|c|c|}
\hline \multirow[b]{2}{*}{ Drugs } & \multirow[b]{2}{*}{$\begin{array}{l}\text { Ionization } \\
\text { mode }\end{array}$} & \multirow[b]{2}{*}{$\begin{array}{l}\text { Accurate } \\
\text { mass /amu }\end{array}$} & \multicolumn{4}{|c|}{ Whole blood } & \multicolumn{4}{|c|}{ Urine } \\
\hline & & & $\begin{array}{l}\text { Retention } \\
\text { time/min }\end{array}$ & $R^{2}$ value & $\begin{array}{l}\text { LOD } \\
/ \mathrm{ng} \mathrm{mL}^{-1}\end{array}$ & $\begin{array}{l}\mathrm{LOQ} \\
/ \mathrm{ng} \mathrm{mL}^{-1}\end{array}$ & $\begin{array}{l}\text { Retention } \\
\text { time/min }\end{array}$ & $\mathrm{R}^{2}$ value & $\begin{array}{l}\text { LOD } \\
/ \mathrm{ng} \mathrm{mL}^{-1}\end{array}$ & $\begin{array}{l}\text { LOQ } \\
/ \mathrm{ng} \mathrm{mL}^{-1}\end{array}$ \\
\hline JWH-018 & Positive & 342.18463 & 19.38 & 0.997 & 0.675 & 0.675 & 19.47 & 0.993 & 1.125 & 1.125 \\
\hline JWH-019 & Positive & 356.20023 & 20.02 & 0.998 & 0.675 & 0.675 & 20.12 & 0.993 & 1.125 & 1.125 \\
\hline JWH-073 & Positive & 328.16898 & 18.61 & 0.994 & 0.675 & 3.375 & 18.69 & 0.996 & 0.225 & 0.225 \\
\hline JWH-081 & Positive & 372.19507 & 19.65 & 0.995 & 0.675 & 0.675 & 19.75 & 0.997 & 0.225 & 0.225 \\
\hline JWH-122 & Positive & 356.20023 & 20.13 & 0.994 & 0.675 & 3.375 & 20.23 & 0.994 & 1.125 & 2.250 \\
\hline JWH-200 & Positive & 385.19031 & 12.65 & 0.972 & 0.675 & 3.375 & 12.61 & 0.994 & 1.125 & 2.250 \\
\hline JWH-250 & Positive & 336.19513 & 18.37 & 0.997 & 0.675 & 0.675 & 18.45 & 0.996 & 1.125 & 1.125 \\
\hline AM-2201 & Positive & 360.17520 & 17.75 & 0.989 & 0.675 & 0.675 & 17.83 & 0.992 & 1.125 & 2.250 \\
\hline$( \pm)-С P ~ 47,497$ & Negative & 317.24854 & 19.00 & * & $*$ & $*$ & 19.10 & $*$ & $*$ & $*$ \\
\hline (С8)-СР 47,497 & Negative & 331.26425 & 19.89 & $*$ & $*$ & $*$ & 19.99 & $*$ & * & $*$ \\
\hline HU-211 & Positive & 387.28876 & 20.25 & 0.996 & 0.675 & 3.375 & 20.33 & 0.992 & 1.125 & 2.250 \\
\hline THC & Positive & 315.23151 & 20.86 & 0.993 & 3.375 & 3.375 & 20.97 & 0.993 & 1.125 & 2.250 \\
\hline 11-OH-THC & Positive & 331.22623 & 17.52 & 0.995 & 3.375 & 3.375 & 17.58 & 0.991 & 3.375 & 3.375 \\
\hline $\begin{array}{l}\text { JWH- } 018 \mathrm{~N}-4 \mathrm{OH} \\
\text { pentyl metabolite }\end{array}$ & Positive & 358.17938 & 15.36 & 0.991 & 0.675 & 0.675 & 15.41 & 0.993 & 1.125 & 2.250 \\
\hline $\begin{array}{l}\text { JWH-073 N-3OH } \\
\text { butyl metabolite }\end{array}$ & Positive & 344.16388 & 15.17 & 0.994 & 0.675 & 0.675 & 15.24 & 0.997 & 1.125 & 1.125 \\
\hline
\end{tabular}

* Indicates results that did not meet the validation criteria.

National Horseracing Authority of Southern Africa for substances below $50 \mathrm{ppb}$ ) for acceptance for linearity were an $R^{2}$ value $\geq 0.970$ and a percentage difference of $\leq 25 \%$ for calibration standards and QCs. In addition, no more than two points were excluded from each set of standards. Failure to meet these criteria resulted in the validation being rejected for the specific compound.

The LOD was determined as the lowest calibration standard which exhibited an $\mathrm{S} / \mathrm{N}$ ratio $\geq 3$, while the LOQ was determined to be the lowest calibration standard which exhibited an $\mathrm{S} / \mathrm{N}$ ratio $\geq 10$.

Accuracy and precision were calculated using the three replicate results for the High QC on four days for urine and three days for whole blood. Accuracy was represented as the difference of the QC High and the theoretical value, and precision as the standard deviation (SD) and coefficient of variance (CV) of the replicates. Acceptance criteria were values within $\leq 25 \%$ of the theoretical values, \% RSD values $\leq 15 \%$, and $C V \leq 10$.

The matrix effect was not fully investigated in this study but urine and whole blood samples were taken from five drug-free volunteers as blank samples. All calibration standards and QCs were prepared in pooled urine or whole blood, respectively, to eliminate any matrix effects.

In this study long-term stability of urine and blood was assessed by storing spiked QCs for 3 months at $4{ }^{\circ} \mathrm{C}$ and at $-20^{\circ} \mathrm{C}$, respectively. In addition freeze-thaw stability of the samples was also assessed (i.e. after being frozen for 3 months the samples were thawed and frozen three times on three consecutive days, then analysed). Only QC High results $\left(4.5 \mathrm{ng} \mathrm{mL}^{-1}\right.$ in urine, and $13.5 \mathrm{ng} \mathrm{mL}^{-1}$ in blood) were used to assess stability.

\section{Results and Discussion}

\subsection{Validation}

No interfering compounds were found in the blank blood or urine samples. All the extracted ion peaks fell within the retention time (0.3 $\mathrm{min})$ and accurate mass (5 ppm) limits.

All of the studied compounds except $( \pm)$-CP 47,497 and (C8)-CP 47,497, showed excellent linearity $\left(\mathrm{R}^{2} \geq 0.970\right)$ and met the criteria for validation as can be seen in Table 1 . The results suggest that the storage conditions of the spiking solution was not ideal for compounds ( \pm )-CP 47,497 and (C8)-CP 47,497, as all the other compounds showed good linearity, where the two mentioned compounds resulted in good linearity only on the first day and very poor linearity on subsequent days. In this instance, Ammann et al. ${ }^{21}$ (who analysed whole blood) also reported several difficulties with these two compounds as well as citing possible matrix effects. These two compounds require negative ionization mode to be detected with LC-MS and showed a lower response possibly indicating a lower ionization efficiency of the ESI source. ${ }^{21}$ This implies that detecting these compounds is more challenging and may require a targeted method which isn't ideal for forensic applications where often a general screening method is required initially. Scheidweiler and Huestis $^{23}$ investigated CP 47,497-type compounds in urine by LC-MS-MS (liquid chromatography coupled with tandem mass spectrometry), and reported good linearity. In the current study, good recoveries were initially observed for ( \pm )-CP 47,497 and (C8)-CP 47,497 in the first batch (102 and $94 \%$, respectively), but the concentration declined rapidly in subsequent batches conducted over time to below detection limits. This indicates that these compounds might be unstable during freeze/thaw cycles or that the storage conditions were not optimal (all batched were spiked from the same initial spiking solution which was kept frozen and defrosted every week). Scheidweiler and Huestis ${ }^{23}$ only studied stability up to 72 hours, and there does not appear to be any longer term stability studies on these compounds. It is possible that this analytical method could be improved for compounds ( \pm )-CP 47,497 and (C8)-CP 47,497, by preparing fresh spiking solution with each batch, as well as including an additional specific internal standard such as

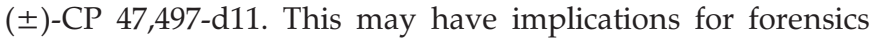
application as these compounds may require a specific targeted method such as that developed by Dowling and Regan ${ }^{24}$ (a LC-MS-MS method specific for CP 47,497 in human urine).

Both the LODs and the LOQs for the analytes ranged between $0.675 \mathrm{ng} \mathrm{mL}^{-1}$ and $3.375 \mathrm{ng} \mathrm{mL}^{-1}$ in whole blood, and between $0.225 \mathrm{ng} \mathrm{mL}^{-1}$ to $3.375 \mathrm{ng} \mathrm{mL}^{-1}$ in urine (seen in Table 1). Seven of the compounds have the same LOD and LOQ values. This is due to the lower calibration standard not fulfilling the criteria of $\mathrm{S} / \mathrm{N}$ ratio $\geq 3$, while the calibration standard above that had an $S / N$ 
ratio $\geq 10$ fulfilling both the LOD and LOQ criteria. In reality, the LOD lies somewhere between the lower and higher calibration standard, however no additional calibration standards were prepared in that range and the exact LOD is not quantifiable from this study. In future studies additional calibration standards could be prepared within this range to determine a more accurate LOD.

Kacinko et al. ${ }^{16}$ determined the LODs for JWH-018, JWH-019, JWH-073, and JWH-250 to be between $0.005 \mathrm{ng} \mathrm{mL}^{-1}$ and $0.020 \mathrm{ng} \mathrm{mL}^{-1}$ in whole blood and the LOQ to be $0.1 \mathrm{ng} \mathrm{mL}^{-1}$ (using UPLC-MS-MS), while Holm et al..$^{25}$ determined the LOD for 13 synthetic cannabinoids (four of which were in common with this project) to be in the $0.1 \mathrm{ng} \mathrm{mL}^{-1}$ to $0.25 \mathrm{ng} \mathrm{mL}^{-1}$ range also in whole blood (using LC-MS-MS). Shanks et al. ${ }^{18}$ found the LOD for their studied synthetic cannabinoids (JWH-018 and JWH-073) in postmortem whole blood to be $0.01 \mathrm{ng} \mathrm{mL}^{-1}$ with a linear range of $0.05 \mathrm{ng} \mathrm{mL}^{-1}$ to $50 \mathrm{ng} \mathrm{mL}^{-1}$.

The higher LODs and LOQs obtained for whole blood could be attributed to the method used that had already been optimized and validated for various other drugs of abuse. If one was only identifying synthetic cannabinoids the method and its analytical testing parameters could be optimized to achieve lower LODs and LOQs. In the postmortem forensic setting the LODs and LOQs from this study are sufficient as most decedents associated with substances of abuse have levels of the substance that is far greater than the LOQs. The lower LODs and LOQs would be significant when attempting to detect trace amounts. A study conducted on postmortem cases to investigate synthetic cannabinoid use as a cause or contributory cause of death included several cases where the levels of several of the synthetic cannabinoids were below the LOD of this study and would thus not be detected, which would be a significant limitation. Labay et al. ${ }^{26}$ studied 25 cases, eight of which had a concentration of various synthetic cannabinoids below the LODs of this study, although four of them also contained additional synthetic cannabinoids which would have been detected. Synthetic cannabinoids were not reported as the cause of death in any of the case studies. The authors concluded that the role of synthetic cannabinoids in the cause and manner of death was still not conclusively defined as many of the cases involved alcohol as well as other drugs.
Scheidweiler and Huestis ${ }^{23}$ validated a similar LC-MS method for 20 synthetic cannabinoids and 21 metabolites in urine (10 of which were in common with this project) from $0.1 \mu \mathrm{g} \mathrm{mL} \mathrm{m}^{-1}$ to $100 \mu \mathrm{g} \mathrm{mL}^{-1}$ (100 $\mathrm{ng} \mathrm{mL}^{-1}$ to $100000 \mathrm{ng} \mathrm{mL}^{-1}$ ), which is significantly higher than the concentration range in this study. Wohlfarth et al. ${ }^{27}$ validated a method for nine synthetic cannabinoids and 20 metabolites (eight of which were in common with this study) in urine and determined their LODs in the range of $0.5 \mathrm{ng} \mathrm{mL}^{-1}$ to $10 \mathrm{ng} \mathrm{mL}^{-1}$, which is comparable to the LODs determined in this project $\left(0.225 \mathrm{ng} \mathrm{mL}^{-1}-3.375 \mathrm{ng} \mathrm{mL}^{-1}\right)$.

The highest calibration standard for the blood validation was $20.250 \mathrm{ng} \mathrm{mL} \mathrm{L}^{-1}$ while the highest calibration standard for the urine validation in this study was $6.750 \mathrm{ng} \mathrm{mL}^{-1}$, resulting in any values above this would fall outside the calibration range of this study. Thus a much larger error would be associated with these values making the method semi-quantitative.

The accuracy of the analytes ranged from $88-107 \%$ in whole blood, with RSD values of between 7.5 and $15.0 \%$ in whole blood (Table 2). These values compare well with those reported by Kacinko et al. ${ }^{16}$ (91.8 and $108.2 \%$ for all tested analytes except JWH-019); Ammann et al. ${ }^{21}$ who reported all analytes to fall within the acceptance interval of $\pm 15 \%$ (i.e. $85-115 \%$ ); and Shanks et al. ${ }^{19}$ (99.1-107.0 \% for JWH-018 and 97.7-102.0 \% for JWH-073).

The accuracy of the analytes ranged from 95-109\% in urine, with RSD values between 4.9 and $11.9 \%$ which are well within the acceptance criteria (Table 2). Due to the low concentration levels of the Low and Medium QCs (falling mostly outside the calibration range), the High QC ( $4.5 \mathrm{ng} \mathrm{mL}^{-1}$ for urine, $13.5 \mathrm{ng} \mathrm{mL}^{-1}$ for whole blood) values were used for all accuracy and precision calculations.

Reported accuracies for similar synthetic cannabinoid metabolites in urine by other cohorts were comparable whilst included in a method which allows for the screening of a large number of different compounds: De Jager et al. ${ }^{28} 73.5-117.5 \%$; Jang et al. ${ }^{29}$ 92-108 \% ; Scheidweiler and Huestis, ${ }^{23}$ 86.5-118.3\%; Simões et al. ${ }^{30}$ 90-115\%.

Many of the analytes were stable over the three months in glass. JWH-018, JWH-073, JWH-081, JWH-200, and JWH-250 in whole blood, appeared to be stable in plastic at all the temperatures as well as being freeze-thaw stable. No stability data for

Table 2 Summary of the accuracy and precision of the high QCs of the synthetic cannabinoids in whole blood $\left(13.5 \mathrm{ng} \mathrm{mL} \mathrm{m}^{-1}\right)$ and urine $\left(4.5 \mathrm{ng} \mathrm{mL} L^{-1}\right)$.

\begin{tabular}{|c|c|c|c|c|c|c|c|c|c|c|}
\hline \multirow[t]{2}{*}{ Drugs } & \multicolumn{5}{|c|}{ Whole blood } & \multicolumn{5}{|c|}{ Urine } \\
\hline & Mean /ng mL $\mathrm{m}^{-1}$ & Accuracy \% & S.D. & $\%$ RSD & $\mathrm{CV}$ & Mean /ng mL $L^{-1}$ & Accuracy \% & S.D. & $\%$ RSD & $\mathrm{CV}$ \\
\hline JWH-018 & 13.745 & 102 & 1.014 & 7.485 & 0.075 & 4.688 & 104 & 0.456 & 9.519 & 0.095 \\
\hline JWH-019 & 13.846 & 103 & 1.369 & 10.020 & 0.100 & 4.675 & 104 & 0.442 & 9.248 & 0.092 \\
\hline JWH-073 & 13.779 & 102 & 1.045 & 7.726 & 0.077 & 4.788 & 106 & 0.333 & 6.883 & 0.069 \\
\hline JWH-081 & 14.467 & 107 & 1.367 & 9.621 & 0.096 & 4.597 & 102 & 0.296 & 6.304 & 0.063 \\
\hline JWH-122 & 13.360 & 99 & 1.521 & 11.389 & 0.114 & 4.791 & 106 & 0.444 & 9.156 & 0.092 \\
\hline JWH-200 & 12.733 & 94 & 1.109 & 8.663 & 0.087 & 4.434 & 99 & 0.218 & 4.909 & 0.049 \\
\hline JWH-250 & 12.751 & 94 & 1.256 & 9.971 & 0.100 & 4.415 & 98 & 0.241 & 5.478 & 0.055 \\
\hline AM-2201 & 11.865 & 88 & 1.219 & 9.851 & 0.099 & 4.266 & 95 & 0.371 & 9.175 & 0.092 \\
\hline$( \pm)-\mathrm{CP} 47,497$ & * & $*$ & $*$ & * & $*$ & * & $*$ & * & $*$ & * \\
\hline (C8)-СР 47,497 & $*$ & $*$ & $*$ & $*$ & * & * & $*$ & * & * & $*$ \\
\hline HU-211 & 13.834 & 102 & 2.020 & 14.579 & 0.146 & 4.885 & 109 & 0.241 & 5.066 & 0.051 \\
\hline THC & 14.210 & 105 & 1.889 & 13.306 & 0.133 & 4.573 & 102 & 0.365 & 7.873 & 0.079 \\
\hline 11-OH-THC & 13.682 & 101 & 1.645 & 12.197 & 0.122 & 4.430 & 98 & 0.434 & 9.629 & 0.096 \\
\hline $\begin{array}{l}\text { JWH-018 N-4OH } \\
\text { pentyl metabolite }\end{array}$ & 12.830 & 95 & 1.052 & 8.196 & 0.082 & 4.610 & 102 & 0.408 & 8.933 & 0.089 \\
\hline $\begin{array}{l}\text { JWH-073 N-3OH } \\
\text { butyl metabolite }\end{array}$ & 12.745 & 94 & 1.473 & 11.577 & 0.116 & 4.327 & 96 & 0.488 & 11.858 & 0.119 \\
\hline
\end{tabular}

* Indicates results that did not meet the validation criteria. 
CP 47,497, (C8)-CP 47,497, HU-211, and 11-OH-THC could be obtained as the concentrations were below the detection limits.

Kacinko et al. ${ }^{16}$ analysed stability of several synthetic cannabinoids in whole blood in plastic containers with several common preservatives and concluded that the collection container did not affect stability at room temperature, refrigerated (approximately $3^{\circ} \mathrm{C}$ ) and frozen (approximately $-10^{\circ} \mathrm{C}$ ) up to 30 days; however, the stability of the compounds longer than that was not investigated. Amman et al. ${ }^{21}$ investigated long-term stability in predominantly JWH-type synthetic cannabinoids, but only up to 42 days. They found all their studied compounds to be stable up to that point.

Storage of urine specimens (for 3 months) in glass at $-20^{\circ} \mathrm{C}$ was best for most of the compounds as higher recovery and lower standard deviations were observed. For the majority of the analytes, storage in plastic containers resulted in lower recoveries and exceptionally high standard deviations. Very high recoveries (i.e. $>100 \%$ ) in several of the samples could be due to factors such as matrix enhancement or unstable compounds in the spiking solution. Initially, the stability samples were prepared at the same time as the spiking solution. The spiking solution was stored frozen but was defrosted with each batch to prepare calibration standards and QC samples. Thus, the stability samples might have had a higher concentration of drug than the QCs and calibration standards. This might suggest a need to prepare a fresh spiking solution so as to eliminate stability challenges. Whilst several studies were undertaken on urine, very few have addressed stability. Three groups did not study stability at all. ${ }^{28,30,31}$ Two groups ${ }^{23,27}$ only investigated stability over 3 days. Only Jang et al. ${ }^{29}$ investigated stability over 30 days (and reported good stabilities, 96-106 \% , for JWH-018 and JWH-073 metabolites).

\subsection{Application to Postmortem Forensic Cases}

The postmortem forensic samples included 126 whole blood and 85 urine samples obtained over a 5-month period, from July 2014 to December 2014. Table 3 provides a summary of the demographic information of the sample population.

An extensive literature search resulted in only one other study conducted on postmortem cases, and no studies involving synthetic cannabinoids in a South African setting. Shanks et al. ${ }^{19}$ analysed 45 postmortem blood cases and found either JWH-018, JWH-073, or both in 18 of the cases. Ammann et al..$^{21}$ validated their method in both antemortem and postmortem blood samples but did not apply their method to actual samples.

Analysing postmortem specimens provides numerous challenges since there are many factors that can influence the concentrations of substances of abuse in a decedent. Among these are postmortem interval (i.e. the time that has elapsed since a person has died), the condition of the body, very little knowledge on in vivo stability of these drugs, as well as postmortem redistribution. In South Africa, bodies can be stored for several days in suboptimal storage conditions, where these factors play an even larger role.

\section{Conclusion}

This study aimed to assess how easily the newer synthetic cannabinoids could be integrated into existing analytical screening methods. The method for urine specimens currently used by the Laboratory of the National Horseracing Authority of Southern Africa, and a whole blood method identified from literature were found to be suitable for majority of the analytes. Both these methods are examples of commonly used methods with common solvents and techniques, allowing for their
Table 3 Postmortem cases summary - Demographic information.

\begin{tabular}{|c|c|c|c|}
\hline Category & Sub-category & $\begin{array}{c}\text { Urine } \\
\% \text { distribution } \\
/ \mathrm{n}=85\end{array}$ & $\begin{array}{c}\text { Blood } \\
\% \text { distribution } \\
/ \mathrm{n}=126\end{array}$ \\
\hline \multirow{6}{*}{$\begin{array}{l}\text { Age group } \\
\text { (years) }\end{array}$} & $15-24$ & 15 & 15 \\
\hline & $25-34$ & 39 & 42 \\
\hline & $35-44$ & 32 & 28 \\
\hline & $45-54$ & 4 & 6 \\
\hline & $55+$ & 4 & 3 \\
\hline & Unknown & 7 & 6 \\
\hline \multirow[t]{4}{*}{ Racial affinity } & Black & 85 & 83 \\
\hline & White & 11 & 11 \\
\hline & Asian & 1 & 2 \\
\hline & Coloured & 4 & 4 \\
\hline \multirow[t]{2}{*}{ Sex } & Male & 92 & 86 \\
\hline & Female & 8 & 14 \\
\hline \multirow{11}{*}{$\begin{array}{l}\text { Circumstance } \\
\text { of death }\end{array}$} & Assault & 2 & 2 \\
\hline & Fall from Height & 8 & 6 \\
\hline & GSW & 28 & 25 \\
\hline & Hanging & 7 & 13 \\
\hline & MVA/MBA/Train & 12 & 9 \\
\hline & Overdose/Poisoning & 2 & 2 \\
\hline & Other & 4 & 6 \\
\hline & PVA & 11 & 10 \\
\hline & Stabbed & 16 & 17 \\
\hline & $\begin{array}{l}\text { Strangulation/ } \\
\text { Suffocation }\end{array}$ & 2 & 2 \\
\hline & Unknown & 7 & 10 \\
\hline
\end{tabular}

GSW $=$ Gunshot wound $; \mathrm{MBA}=$ Motorbike accident; $\mathrm{MVA}=$ Motorist vehicle accident; PVA = Pedestrian vehicle accident; others include burns electrocution, and gassing.

potentially easy implementation into local forensic laboratories.

Overall, the majority of the studied synthetic cannabinoids exhibited excellent linearity $\left(R^{2} \geq 0.990\right)$, as well as good LODs and LOQs, i.e. $0.225 \mathrm{ng} \mathrm{mL}^{-1}$ and $3.375 \mathrm{ng} \mathrm{mL}^{-1}$ for urine, and $0.675 \mathrm{ng} \mathrm{mL}^{-1}$ and $3.375 \mathrm{ng} \mathrm{mL}^{-1}$ for whole blood, respectively.

The methods were not successfully validated for ( \pm )-CP 47,497 and (C8)-CP 47,497 as ionization efficiency and stability issues were encountered. Future work on urine samples could also be extended to the evaluation of other synthetic cannabinoid metabolites, as this study focused mainly on the parent components and only two metabolites were analysed. Further optimization of negative mode parameters may also improve the signal intensity and provide better results.

The use of LLE extraction is ideal for the South African environment as it is easy to perform, large numbers can be processed simultaneously, and it requires minimal equipment and apparatus (basic glassware is sufficient).

The validation data indicated that the adaptation of existing routine screening methods to include several synthetic cannabinoids was mostly successful. This method provides a sensitive as well as selective way of screening for JWH-018, JWH-019, JWH-073, JWH-081, JWH-122, JWH-200, JWH-250, AM-2201, HU-211, THC, 11-OH-THC, JWH-018 N-4OH pentyl metabolite, and JWH-073 N-3OH butyl metabolite in urine and whole blood.

From the results obtained the scope of research should be widened to include groups such as drug rehabilitation centres and seized drugs to obtain a more accurate representation of the 
extent to which these drugs are being used in South Africa. If further research amongst these groups were to yield negative results, it would provide evidence of low prevalence of these synthetic cannabinoids in South Africa. If, however, positive results were found, the South African Police Services Forensics Science Laboratories would need to consider adding a screening test like the one presented in this study to their testing protocols.

\section{Acknowledgements}

We thank Dr Magda Rosemann and the Laboratory of the National Horseracing Authority of Southern Africa for the use of their laboratory facilities and extensive assistance with this project, the National Research Foundation for funding, the University of the Witwatersrand, Faculty of Health Sciences, Faculty Research Committee for an Individual Research Grant (Grant Number: 0012548465101512110500000000000000004206), and the Johannesburg Forensic Pathology Services Medicolegal Laboratory for the use of their facilities as well as assistance in sample collection.

\section{ORCID iDs}

D. Pon:

I.J. Fenyvesi:

orcid.org/0000-0002-9880-5979

orcid.org/0000-0002-0636-0934

\section{References}

1 A. Auwärter, S. Dresen, W. Weinmann, M. Müller, M. Pütz and N. Ferreirós, "Spice" and other herbal blends: harmless incense or cannabinoid designer drugs?, J. Mass Spectrom., 2009, 44, 832-837.

2 N. Uchiyama, R. Kikura-Hanajiri, N. Kawahara, Y. Haishima and Y. Goda, Identification of a cannabinoid analog as a new type of designer drug in a herbal product, Chem. Pharm. Bull. (Tokyo), 2009, 57, 439-441.

3 T. Reed. K2: Easily accessible substance that mimics marijuana - and is legal - sold in Ann Arbor http://www.annarbor.com/news/easily-accessible-substance-that-mimics-marijuana--and-is-legal--so ld-locally/ (accessed 19 February 2016).

4 Buy K2 incense http://www.theofficialk2incense.com/buy-k2incense/ (accessed 19 February 2016).

5 M.B. Forrester, K. Kleinschmidt, E. Schwarz and A. Young, Synthetic cannabinoid exposures reported to Texas Poison Centers, J. Addict. Dis., 2011, 30, 351-358.

6 M. Hermanns-Clausen, S. Kneisel, B. Szabo and V. Auwärter, Acute toxicity due to the confirmed consumption of synthetic cannabinoids: clinical and laboratory findings, Addiction, 2013, 108, 534-544.

7 M. Hermanns-Clausen, S. Kneisel, M. Hutter, B. Szabo and V. Auwärter, Acute Intoxication by synthetic cannabinoids - Four case reports, Drug Test. Anal., 2013, 5, 790-794.

8 D. Papanti, F. Schifano, G. Botteon, F. Bertossi, J. Mannix, D. Vidoni, M. Impagnatiello, E. Pascolo-Fabrici and T. Bonavigo, "Spiceophrenia": A systematic overview of "Spice"-related psychopathological issues and a case report, Hum. Psychopharmacol. Clin. Exp., $2013,28,379-389$.

9 L.D. Johnston, P.M. O'Malley, J. G. Bachman and J. E. Schulenberg, Monitoring the Future - National Results on Drug Use - 2012 Overview Key Findings on Adolescent Drug Use; 2012.

10 Global Drug Survey. Mixmag/Guardian Drugs Survey http://issuu.com/mixmagfashion/docs/drugs_survey_2012_2?e $=0$

11 M.J. Barratt, V. Cakic and S. Lenton, Patterns of synthetic cannabinoid use in Australia, Drug Alcohol Rev., 2013, 32, 141-146.

12 A. Scott, N. Gately and J. Fleming, Synthetic Cannabinoids: Perceptions and Prevalence amongst Australian Police Detainees, Pre and Post Legislation; 2012.

13 S. Kneisel and V. Auwärter, Analysis of 30 synthetic cannabinoids in serum by liquid chromatography-electrospray ionization tandem mass spectrometry after liquid-liquid extraction, J. Mass Spectrom., $2012,47,825-835$.

14 S. Dresen, S. Kneisel, W. Weinmann, R. Zimmermann and V.
Auwärter, Development and validation of a liquid chromatography-tandem mass spectrometry method for the quantitation of synthetic cannabinoids of the aminoalkylindole type and methanandamide in serum and its application to forensic samples, J. Mass Spectrom., 2011, 46, 163-171.

15 J. Teske, J.-P. Weller, A. Fieguth, T. Rothämel, Y. Schulz and H.D. Tröger, Sensitive and rapid quantification of the cannabinoid receptor agonist naphthalen-1-Yl-(1-pentylindol-3-Yl)methanone (JWH018 ) in human serum by liquid chromatography-tandem mass spectrometry, J. Chromatogr. B, 2010, 878, 2659-2663.

16 S.L. Kacinko, A. Xu, J.W. Homan, M.M. McMullin, D.M. Warrington and B.K. Logan, Development and validation of a liquid chromatography-tandem mass spectrometry method for the identification and quantification of JWH-018, JWH-073, JWH-019, and JWH-250 in human whole blood, J. Anal. Toxicol., 2011, 35, 386-393.

17 R. Gottardo, A. Chiarini, I. Dal Prà, C. Seri, C. Rimondo, G. Serpelloni, U. Armato and F. Tagliaro, Direct screening of herbal blends for new synthetic cannabinoids by MALDI-TOF MS, J. Mass Spectrom., 2012, 47, 141-146.

18 K.G. Shanks, T. Dahn, G. Behonick and A.R. Terrell, Analysis of first and second generation legal highs for synthetic cannabinoids and synthetic stimulants by ultra-performance liquid chromatography and time of flight mass spectrometry, J. Anal. Toxicol., 2012, 36, 360-371.

19 K.G. Shanks, T. Dahn and A.R. Terrell, Detection of JWH-018 and JWH-073 by UPLC-MS-MS in Postmortem whole blood casework, J. Anal. Toxicol., 2012, 36, 145-152.

20 Inquests Act 58 of 1959; SA Parliament, 1959.

21 J. Ammann, J.M. McLaren, D. Gerostamoulos and J. Beyer, Detection and quantification of new designer drugs in human blood: Part 1 Synthetic cannabinoids, J. Anal. Toxicol., 2012, 36, 372-380.

22 SANAS, Recommended Guidelines for the Verification and Validation of Methods in Forensic Chemistry - TG 41-01, 2008.

23 K.B. Scheidweiler and M.A. Huestis, Simultaneous quantification of 20 synthetic cannabinoids and 21 metabolites, and semi-quantification of 12 alkyl hydroxy metabolites in human urine by liquid chromatography-tandem mass spectrometry, J. Chromatogr. A, 2014, 1327, 105-117.

24 G. Dowling and L. Regan, A method for CP 47, 497 a synthetic non-traditional cannabinoid in human urine using liquid chromatography tandem mass spectrometry, J. Chromatogr. B, 2011, 879, $253-259$.

25 N.B. Holm, R.S. Pineda, D.W. Andersen, B.S. Rasmussen, P.W Dalsgaard, L.C.G. Hoegberg, S.S. Johansen and K. Linnet, Screening of Danish traffic cases for synthetic cannabinoids in whole blood by LC-MS/MS, Scand. J. Forensic Sci., 2013, 19, 1-7.

26 L.M. Labay, J.L. Caruso, T.P. Gilson, R.J. Phipps, L.D. Knight, N.P. Lemos, I.M. McIntyre, R. Stoppacher, L.M. Tormos, A.L. Wiens, et al., Synthetic cannabinoid drug use as a cause or contributory cause of death, Forensic Sci. Int., 2016, 260, 31-39.

27 A. Wohlfarth, K.B. Scheidweiler, X. Chen, H. Liu and M.A. Huestis, Qualitative confirmation of 9 synthetic cannabinoids and 20 metabolites in human urine using LC-MS/MS and Library Search, Anal. Chem., 2013, 85, 3730-3738.

28 A.D. de Jager, J.V Warner, M. Henman, W. Ferguson and A. Hall, LC-MS/MS Method for the quantitation of metabolites of eight commonly-used synthetic cannabinoids in human urine - an Australian perspective, J. Chromatogr. B, 2012, 897, 22-31.

29 M. Jang, W. Yang, H. Choi, H. Chang, S. Lee, E. Kim and H. Chung, Monitoring of urinary metabolites of JWH-018 and JWH-073 in legal cases, Forensic Sci. Int., 2013, 231, 13-19.

30 S.S. Simões, I. Silva, A.C. Ajenjo and M.J. Dias, Validation and application of an UPLC-MS/MS method for the quantification of synthetic cannabinoids in urine samples and analysis of seized materials from the Portuguese market, Forensic Sci. Int., 2014, 243, 117-125.

31 A. Grigoryev, S. Savchuk, A. Melnik, N. Moskaleva, J. Dzhurko, M. Ershov, A. Nosyrev, A. Vedenin, B. Izotov, I. Zabirova, et al., Chromatography-mass spectrometry studies on the metabolism of synthetic cannabinoids JWH-018 and JWH-073, psychoactive components of smoking mixtures, J. Chromatogr. B, 2011, 879, 1126-1136. 